\title{
Alexander, Frankenstein and regular days in the life of a Balkan archaeologist. The experience of the Greek - Albanian Archaeological Expedition at Prespa (Albania), in the years 2009 - 2014
}

\author{
*Stavros OIKONOMIDIS, **Aris PAPAYIANNIS, ***Akis TSONOS \\ * Adjunct Professor of Archaeology, Arcadia University, College for Global Studies, Glenside, U.S.A., \\ Arcadia Center, Athens, Greece \\ President of the ITCC, Co - Director of the Greek - Albanian Archaeological Expedition at Prespa \\ Email: ekedimos@yahoo.gr, oikonomidiss@arcadia.edu \\ ** Archaeologist, University of Crete, E’ Ephorate of Prehistoric and Classical Antiquities (Sparta, Greece), \\ Treasurer of the ITCC Email: arispapag33@yahoo.gr \\ *** Archaeologist, $\mathrm{PhD}$ cand., University of Ioannina (Greece), \\ Secretary of the I.T.C.C. Email: akis_tsonos2000@yahoo.com
}

\begin{abstract}
This is a short account of how archaeology and archaeologists could become protagonists of a political psychodrama, very common in an ancient land like the Balkans. Old and rich heritages often are responsible for the bad relations occurred among people who in reality have nothing to divide except from the ghosts of presumed ancient ancestors. Alexander described here is not the King of Macedonia and Asia but his Frankensteinish version, which was created, fed and grown like a Prague's Golem in order to be used as a puppet in the hands of able manipulators. The case of the Greek - Albanian Archaeological Expedition on the island of Maligrad, in the Tri - National zone of Prespa, is given as an example of how things work some times in our days, in places which have never been something else than "grey zones" on the map. The case of the "recent" discovery of the Macedonian tomb at Amphipolis, Greece, is given here as a counter balance to the case of Maligrad. The polemic of the article is not focusing on cultural or demographic minorities of any place in the Balkans but on the ill use of our common historical heritage by political authorities.
\end{abstract}

Key Words: Alexander, Ghost, Political manipulation of Archaeology, Pedigree, Panacea 


\section{The genesis of an archaeological project}

The idea of digging on Maligrad popped out a sunny day of February, in 2007, in a room of the Greek - Orthodox guest house, at Korcë. Professor Lera, Albanian archaeologist, representative of the Albanian State for the archaeological affairs of the Korcë District (SE Albania), brought us the new issue of Tempulli, the local cultural review. A rather unclear image of the island, on a black and white picture, was shown, giving us the impression of Stevenson's Island of the Pirates (Lera 2007). The somehow metaphysical impact that Maligrad's picture had on us played a definite role on the decision, which would come a little later, to visit it soon. A couple of weeks later, a windy Sunday, we were crossing the passage between Liqenas and the island, on a typical iron fishing boat, full of expectations for our first visit. After our first stop few meters outside from the Late Byzantine chapel of Virgin Mary and our astonishment, which was related to the wonderful external frescos of the beautiful building, we were following professor Lera's steps to the flat top of Maligrad, identical to a unique natural balcony facing the entire Great Prespa Lake and its surroundings (Lera et al., 2009; Lera et al., 2013; Lera et al., in press; Oikonomidis et al., 2013). The most fantastic view of such a landscape was there, before our eyes, maybe the best natural setting of the Balkans. The wind was brushing the yellowish vegetation, and the colors of the mountains, Mal i Thate, Grammos, Voion, and Marica were discovered to belong, for each of them, to a different chromatic scale.

Professor Lera is one of the few great connoisseurs of the lands of SE Albania, with a fascinating archaeological experience which counts 50 years of surveys, mappings and excavations in the area. He is the man who taught us this part of Albania, and the secrets of this really rich archaeological district. He knew perfectly well every single inch of Maligrad and he had for the first time brought to the interest of the public the red ochre paintings of the island, organizing a first approach to his students with the archaeology of Prespa, a couple of years earlier. Maligrad! There was an entire universe made from byzantine hermitages and chapels, diachronic rock - art, visible roman remains and sherds found all over its surface that could be dated to, at least, three millennia of history. By that time we were teaching Theory of Archaeology at the State University of Korcë, once a month and at the same time we were learning Albania with long surveys and travels all over the district, always guided by the gifted Professor Lera. The idea of getting deeper into the Albanian archaeology was only a first shy motion of a certain desire which we were sharing since our first common visit to the country. However, during our early Albanian years our archaeological activity should be limited to traveling and reading only.

Between 2007 and 2008 our Syllabi presented at the University would give a chance to the students of the Pedagogical Department to know something more about what archaeology is in our days. The kids proved to be really curious on the matter and they appreciated the fact that the approach was not at all the expected one ${ }^{1}$. After working with these students for several semesters we formed our first working team, ready to face together the field work out there at Prespa and surroundings, more precisely on Maligrad.

\footnotetext{
${ }^{1}$ Not the expected political propaganda.
} 


\section{The Greek - Albanian Project on Maligrad (Fig. 1-2)}

Maligrad occupies a strategic position at the westernmost edge of the Great Prespa Lake and it has been a natural landmark, visible from miles, on the crossroad of a complex road system of Western Macedonia (Oikonomidis et al., 2013; Oikonomidis, in press; Oikonomidis, forthcoming). Because of its geographic position between Illyria and Macedonia Maligrad resulted to become the first site of a long term archaeological investigation which would be promoted under the auspices of the Albanian State and shared by both Albanian and Greek archaeologists (Lera et al., 2011; Lera et al., 2013; Lera et al., in press). The experiment would be revealed successful, and at the same time a fair collaboration between the Albanian Archaeological Institute of Tirana and the Institute of Trans Balkan Cultural Cooperation of Athens (I.T.C.C.).

The program would embrace all kinds of a field - work, with the assistance of specialists who would guarantee a complete investigation on the island and in the lab. Greek, Albanian, Montenegrin, and American students would learn how to dig, while Slav Macedonian technicians and workers would assist in any possible way the excavation (Lera et al., forthcoming). The thing worked well, it always does when peaceful people share common interests without useless polemics. The archaeological data spoke the truth, as always does, giving the image of a diachronic habitation since, at least, the Middle Bronze Age. Maligrad proved to be among the most important sites of the Tri - National zone ${ }^{2}$, with pottery coming from the prehistoric - early historic - archaic - classic - Hellenistic - early to late Roman and Byzantine to late and post Byzantine strata. Despite the historical gaps occurred in the area between the $4^{\text {th }}$ and the middle $6^{\text {th }}$ centuries CE the archaeological data from Maligrad offered for the first time valid information about the bloodiest moments of the $1^{\text {st }}$ millennium of our Era.

\section{The importance of Maligrad}

After a sequence of undisturbed archaeological layers, about a millennium of continuous peaceful existence and with no remarkable stratigraphic alterations the last settlement on Maligrad $^{3}$ would be destroyed by invaders who exterminated the population during a violent riot $^{4}$. It seems that few survivors came back in order to bury fast their families but without rebuilding the settlement (Lera et al., in press) ${ }^{5}$. Important archaeological elements, such as the discovery of an iron - head ${ }^{6}$ into the left eye of one of the victims (Lera et al., in press), show the probable identity of the invaders. In the first half of the $6^{\text {th }}$ century the entire Balkan Peninsula suffered from numerous invasions of the Avars, and the Avaro - Slavs who were in

\footnotetext{
${ }^{2}$ The Tri - National zone of Prespa belongs to Albania, Greece, FYROM, respectively.

${ }^{3}$ A settlement of fishermen made from wooden huts. The most elaborate architecture found on Maligrad belongs to the late Hellenistic/early Roman period when the houses were built from local limestone and having flat clay roof - tiles. During that period the houses would have a chess - board planning on the lower plateau of the island.

${ }^{4}$ A percentage of 5/7 of the skeletal remains presented evident signs of violent death, with skulls smashed, decapitated heads and arms cut or broken.

${ }^{5}$ The momentum of the destruction was dated by two coins of the early Justinian time, coined in Thessaloniki.

${ }^{6}$ Which belongs to the Avaro - Slavic type of arrow - head.
} 
search of a new homeland. During that period of serious demographic turmoil, is that the medieval character of the national identities in the Balkans was created, changing dramatically the previous ethnic conditions in the area for ever. Though, the greatest discovery on Maligrad was its stratigraphic data, its dramatic end gives the stigma of the conclusion of an era and the start of another. After the creation of the cemetery over the ruined walls of the last settlement, which would cover almost all the trapezoidal top of Maligrad, nobody came back again, with the exception of the hermits and the anachoretes, 7 centuries later ${ }^{7}$.

\section{The ghost of Alexander invades Maligrad}

It was the day that the first skeletons had to be removed from Maligrad to the nearby village of Liqenas $^{8}$ that we started to realize how difficult could be such an easy job, apparently. To the eyes of superstitious old women the idea would appear outrageous because some "old corpses" were traveling to their village, who knows with what kind of unexpected metaphysical results. There were suspicious eyes looking at the fishing boats coming nearer and nearer from Maligrad to the village, mouths were talking about reemerging evil spirits and a voice asking all the time: "Who were they? Were they good Christians"? The idea that the human remains, objects of study to us, might belong to the "people of Alexander", came a little later.

Alexander! For Greeks, Slav Macedonians, Albanians, Bulgarians and the rest of the Balkan Universe was, is and will be to the end of Time a patriotic symbol, the ideal of the political and military leader and above all the best tool to create and support the necessary background for planning and then inventing a nation - state. Alexander, their Alexander, not the real historical persona, would become flag, logo, and excuse for advancing pseudo - ancient legends and pseudo - archaeological theories about modern boarders in the area. Alexandros of Pseudo - Callimachos, and of Sisois the hermit, Ishkandar the Prophet of the Quran, Alexander as the lost Apostle of the Nations, Alexander as the Holy Ghost of the Holy Balkans, Alexander as a racial guarantee for those who still imagine themselves as his potential descendants, between Skopje and Litochoro. The creation of another Alexander, who would be played as a puppet in the hands of funny presidents and local mayors with imperial ambitions, of self - defined supporters of the ideals of freedom, dressed in the last many centuries, with innumerable variations of the Balkan short kilt, would be profitable and extremely fruitful, talking in terms of political propagandas of any possible and imaginable style and fashion, in the area. The invented ghost of this imaginary Alexander would be made from different parts but following always the same motives: the necessity of guaranteeing forgotten ancestries and consequently of guaranteeing lands from the respective neighbors. The supposed discovery of every single proof of this comic pedigree should be used as a regular weapon against the arrogant claims of the others. Dressed with the costume of Frankenstein this Alexander, created as a Golem to haunt starved political logistics of the

\footnotetext{
${ }^{7}$ Interesting is the local legend according to which on Maligrad was built the summer residence of Samuel's daughter in the early 11th century, reflecting the era of the active Bulgarian domination of the area and the transferring to Prespa of the royal capital, by Samuel, King of the Bulgarians.

${ }^{8}$ Liqenas or Pusteç is the biggest village of the Slav Macedonian minority of the Albanian sector of Prespa Lake.
} 
Balkans, became our nightmare the day that an enlighten TV reporter from Former Yugoslav Republic of Macedonia (FYROM) asked the big question: "do the skeletons belong to soldiers of Alexander the Great?" the local people forgot their folkloric superstitions with the black terrors of the classical undead 'vorvolak' and they starred us with open mouths, expecting our reaction. The answer was: 'what are you talking about'? (Lera et al., 2013: 126-129; Lera et al., forthcoming).

Since that question was made, the research on Maligrad brought to light much more stratigrafic and other data and of course nobody of us kept the question on mind any more, until the few last working days in the summer of 2014 when the big attack occurred, in the middle of the busiest moments of the excavation. A voice was spread out according to which the "Greeks" discovered important archaeological remains on Maligrad, related to Alexander the Macedon, and that they were forging the data in order to falsify the local history, advancing the "noxious Greek theories on Macedonia". The skeletons which were removed away from the island belonged to Alexander's soldiers... The sudden news was not expected after several years of peaceful work at Prespa. Who would ever imagine that the not casual mention of a name like Alexander's, out of context on Maligrad, would create such a mess in our between relations, the Slav Macedonian minority of the Tri - National and the Greek Albanian expedition at Prespa. For them, we thought, Alexander was a kind of panacea to their daily troubles. They are just trying to be proud of their origins, supposed or true, but it could be something more, hidden below the apparently innocent/naïve question about "Alexander's soldiers" of Maligrad. After a long diplomatic war between Greece and FYROM about finalizing the question of the name of the newest Republic of the Balkans", after a bloody background which involved Greeks, Bulgarians and Slav Macedonians in the early $20^{\text {th }}$ century in the area ${ }^{10}$, after the still open question about Kosovo and the contested national border between Albania, Kosovo and FYROM, a Greek - Albanian archaeological expedition taking place in "their" land, without asking any permits from the local mayor, was too much (Lera et al, forthcoming).

But how could we blame them when an entire country, Greece, a couple of months later would freeze before the unexpected good news about the "discovery"11 of a Royal Macedonian tomb, in the outskirts of Serres? Once again, this time not at the Tri - National zone but in Macedonia of the northern Aegean Sea, Alexander and his colorful royal imperial court would appear as panacea to the malady of the economic crisis, or if you prefer, as one more proof of "Greekness" of northern Greece to show to the rest of the Balkan neighbors, who are supposedly ready all the time to claim the rich southern lands, in order to take control of the Macedonian harbors ${ }^{12}$. It is the ghost of Alexander once again who is

\footnotetext{
${ }^{9}$ Greece denies the use of the word Macedonia to FYROM due to historical reasons.

${ }^{10}$ It is the famous Struggle for Macedonia, $1904-1908$.

${ }^{11}$ The internationally famous now tomb of Amphipolis which in reality was very well known to the archaeological authorities of Greece since the mid 1960's and "rediscovered" at a particularly crucial moment of economic and political crisis for the country.

${ }^{12}$ In reality the political manipulation of ancestral symbols dates back to the antiquity. Alexander has been a victim of this kind of manipulation himself after his death. The Diadochs to the throne of his immense empire fought cruel battles in order to take his dead body and turn it into a symbol which would guarantee the succession to power. Only the "owner" of the body of Alexander's would be considered the real heir to the throne. Ptolemy
} 
haunting the territories which once belonged to his ancient kingdom. Once more, politicians mixed with archaeologists, diplomats and the mass media are guiding the psychodrama of a country of the Balkans.

It's the Balkans here: people talking all day long about the "new" archaeological discovery, are experiencing a national phrenitis, expecting to see with their own eyes something strong, something speaking to their hearts; complexes coming out from an interminable economic crisis and from a social turmoil which is more than visible in the last 5 years in Greece, push the popular interest to the semi imaginative glorious past of Alexander's, back to the times when Greece was not humiliated by any loan giver and when the "enemies" were all standing on a line, heads down, in front of the biggest leader in history. It is the moment when people who are most of the times careless about "antiquities" and archaeology turn to be proud about their origins; real or supposed, imaginative or created, desired or suggested.

FYROM, Greece, Bulgaria, Albania are the protagonists and at the same time the victims of well calculated manipulations of various origins. Forged inscriptions, archaeological data, presumed ancestries which in reality count less than a dog's pedigree, are put on the table, after popping out from forgotten cabinets and lugubrious archives, used as a remedy for all illnesses. We don't know how things are going to be in the next archaeological dig on Maligrad. We are going to have our permits, issued by the authorities of the country we work with, we will keep studying the stratigraphy and we will "read" the only fair historians who wrote the most reliable account on the human deeds: the earth and its archaeological layers. Away from ghosts! As possible!

It's play - time guys! Let's play!

\section{REFERENCES}

Lera, P (2007). Zbulohet një pikturë shkembore në ishullin e Maligradit në Liqenin e Prespes së madhë. Tempulli 12: 37-42.

Lera, P, Oikonomidis, St, Papayiannis, Ar, and Tsonos, Ak (2008). Maligradi në vrojtimet tona arkeologjike. Tempulli 13: 60-69.

Lera, P, Oikonomidis, St, Papayiannis, Ar, and Tsonos, Ak (2009). "Settlement Organization and Social Context in the SW Balcanic Peninsula (Epirotic and Albanian Coast) and Northern Italy during the transitional Period between the Late Bronze Age and the Early Iron Age (13th-9th BC)". In From the Aegean to the Adriatic: social organisations, modes of exchange and interaction in the Post-palatial Times (12th-11th B.C.) (Eds, Borgna, E. and Cassola Guida P). Atti del Seminario internazionale, Udine, 1-2 dicembre 2006, Studi e Ricerche di Protoistoria Mediterranea 8, Quasar, Roma: 325-343.

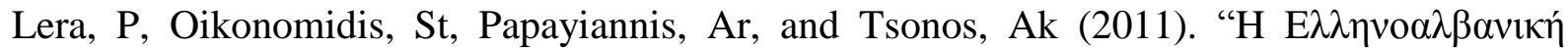

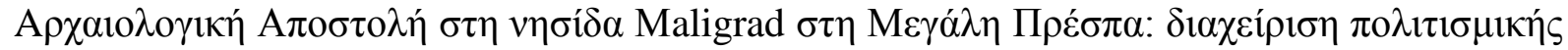

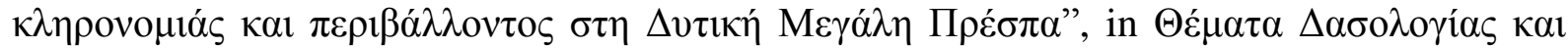

kidnapped the body and he transported it to Egypt, where he managed to establish a successful dynasty of Macedonian Pharaohs. 


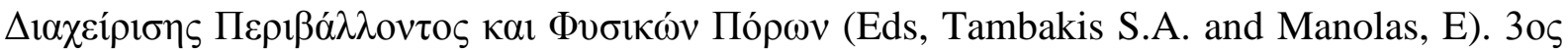

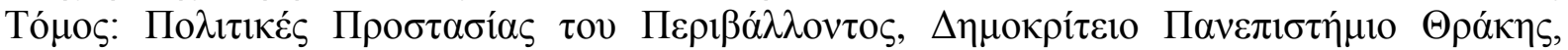

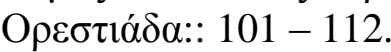

Lera, P, Oikonomidis, St, Papayiannis, Ar, and Tsonos, Ak (2013). The Greek-Albanian Archaeological Project on Maligrad: Shaping the Cultural Heritage in the Tri-National Zone of the Great Prespa Lake. Journal of Conservation and Management of Archaeological Sites 15, 1 (2013): 121-134.

Lera, P, Oikonomidis, St, Papayiannis, Ar, Tsonos, Ak (forthcoming). "Being multilingual in the Great Prespa Lake. Examining the diachronic cultural and political boundaries in no man's land". In Balkan Dialogues. Spatial Boundaries and Cultural Identities in the Prehistoric Balkans. Internationales Wissenschaftsforum Heidelberg, 2nd-3rd May 2014, Heidelberg, organized by M. Ivanova and M. Gori.

Lera, P, Oikonomidis, St, Papayiannis, Ar, Tsonos, Ak, Oikonomou, Ar., Gkotsinas, Ag. (in press). "The Greek-Albanian Archaeological Expedition at Prespa: 2009-2013. The most recent results". In International Congress of Albanian Archaeological Studies, Center of Albanological Studies, Institute of Archaeology, Tirana, 21-22 November 2013.

Oikonomidis, St (forthcoming). Fortresses of frontier between Macedonia and Illyria in the Early Iron Age, In $3^{\text {rd }}$ Archaeological Meeting of Ano Macedonia, Aiani, 14-15 December 2013

Oikonomidis, St (in press). Terra Limitanea: ancient lacustrian, fluvial and mountain passes in the Prespa district, Enalia XII

Oikonomidis, St, Papayiannis, Ar, and Tsonos, Ak (2013). The Lake Prespa Area: A Geographic and a historic approach to the Tri-National District. Epirotic Chronicles 45 (20112013): 9-50 


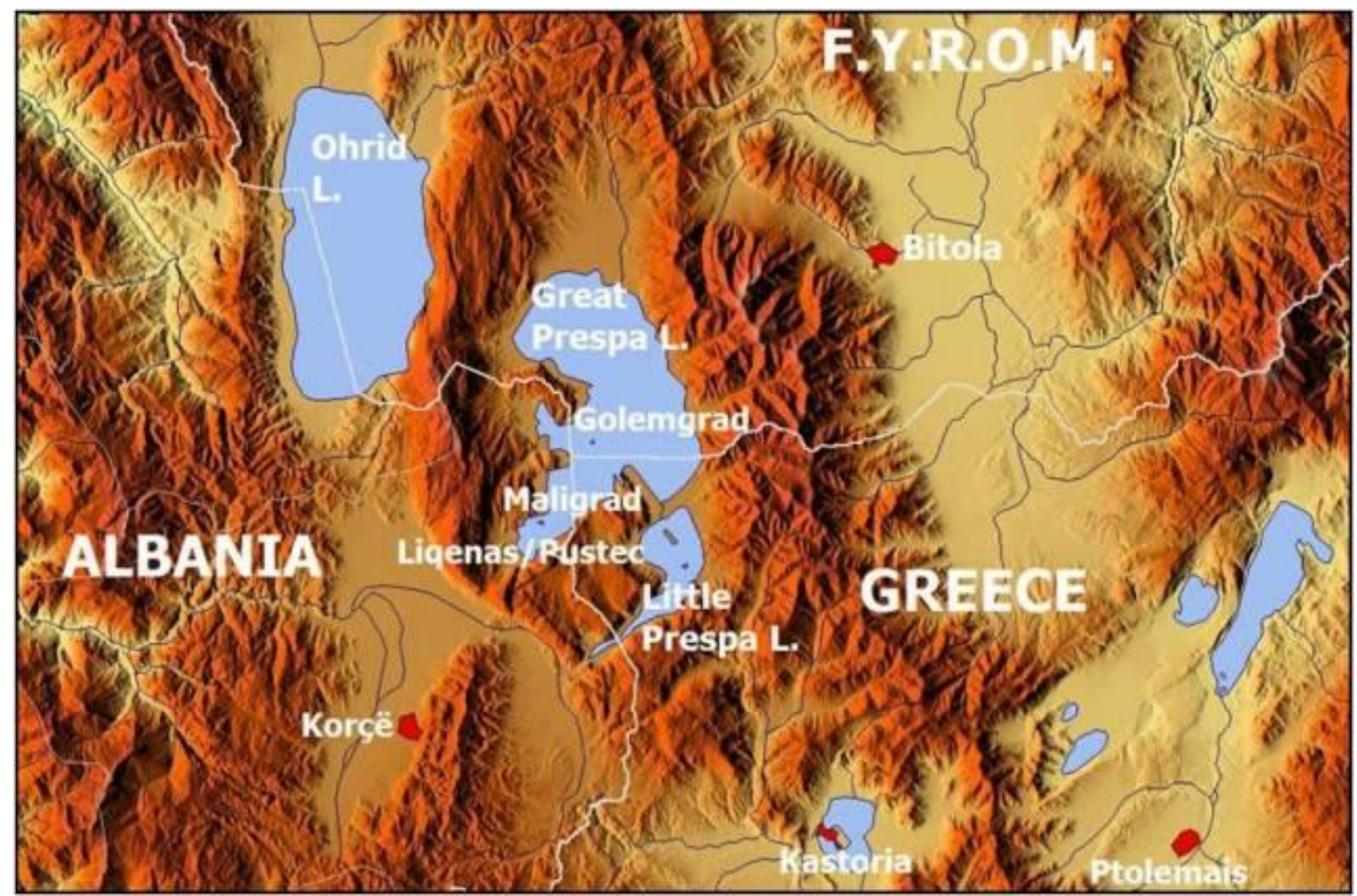

Fig. 1. Map of the Tri - National zone between FYROM, Greece and Albania
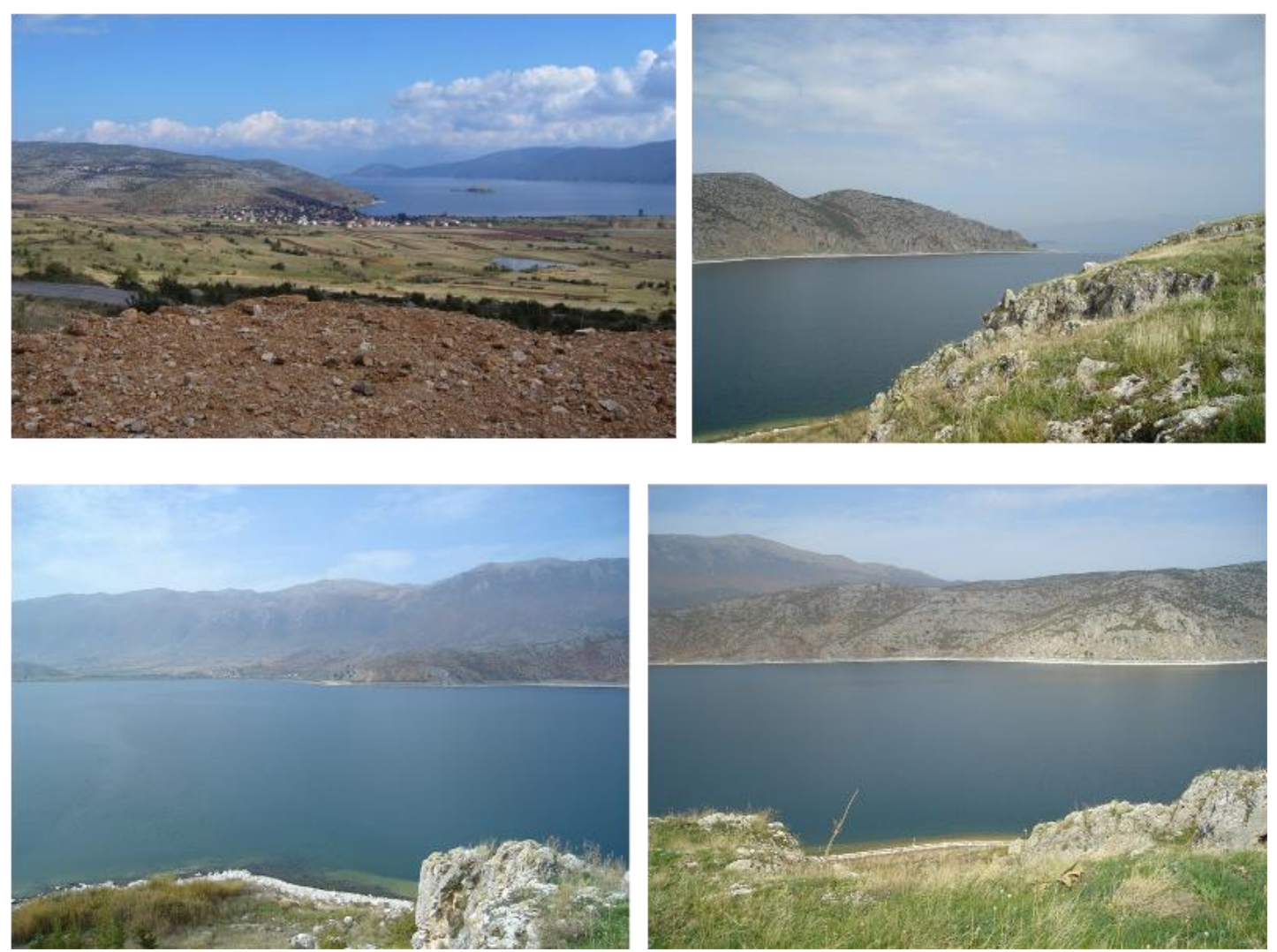

Fig. 2. The islet of Maligrad and views of the Tri - National Zone from the top of Maligrad. 